EGG-CIET-11399

\title{
Nitrate Analysis of Snow and Ice Core Samples Collected in the Vicinity of a Waste Detonation Event, McMurdo Station, Antarctica
}

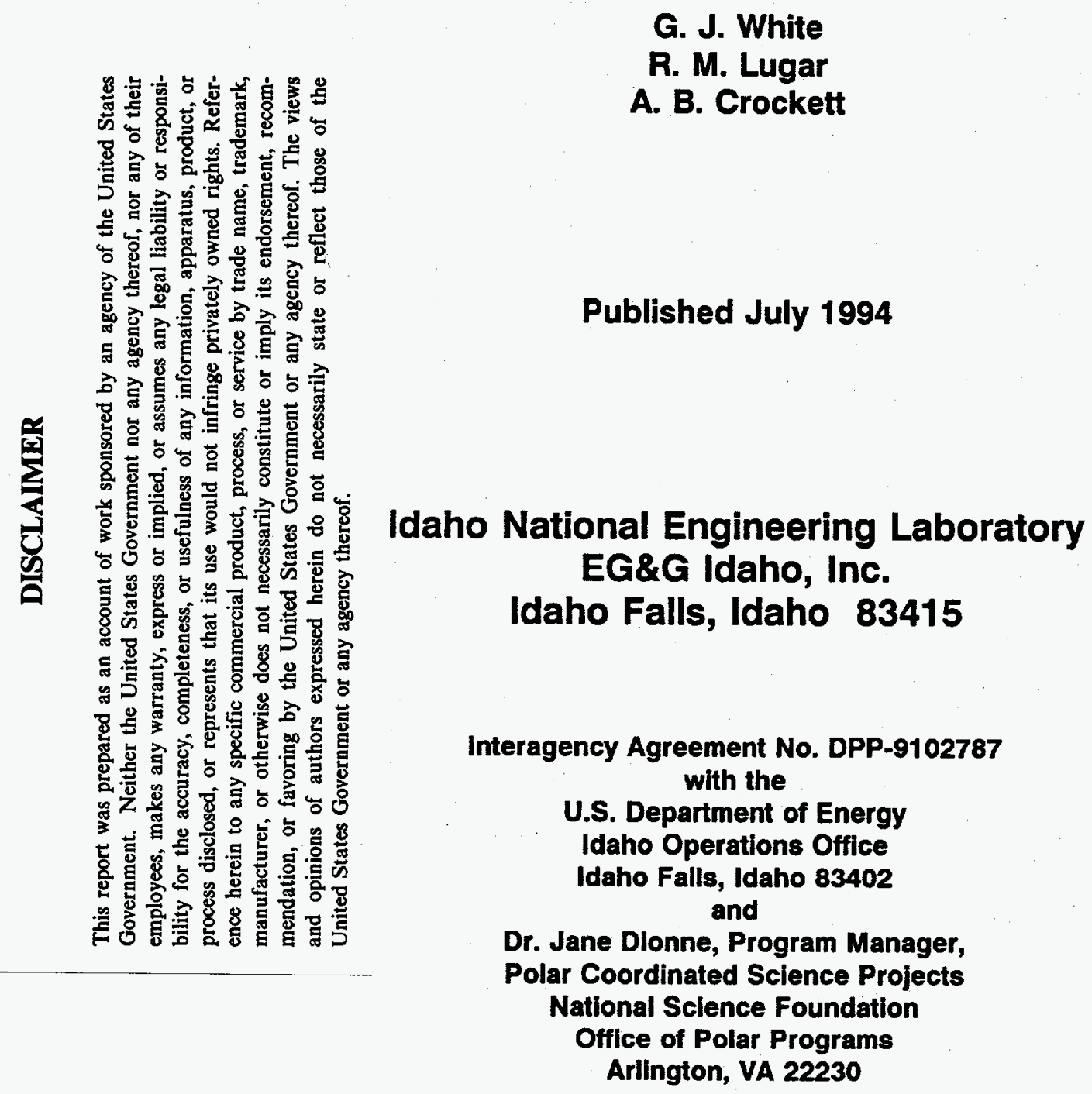




\section{DISCLAIMER}

Portions of this document may be illegible in electronic image products. Images are produced from the best available original document. 


\section{ABSTRACT}

On December 30, 1991, a small quantity of hazardous materials was detonated at a site near McMurdo Station, Antarctica. The materials involved in the detonation represented highly reactive or explosive wastes that could not be transported safely for disposal in the United States. Detonation was therefore considered the safest and most effective means for disposing these hazardous materials. One concern regarding the detonation of these substances was that the process could generate or distribute measurable quantities of contaminants to the area surrounding the detonation site. Nitrate was selected as a tracer to document the distribution of contaminants from the detonation. Snow and ice cores were collected about 4 months after the event. These cores were analyzed for nitrate concentrations in May 1993, and a map was generated to show the extent of nitrate contamination. This report describes the collection of these samples and summarizes the analytical results. 



\section{CONTENTS}

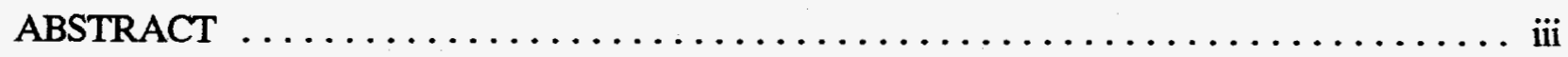

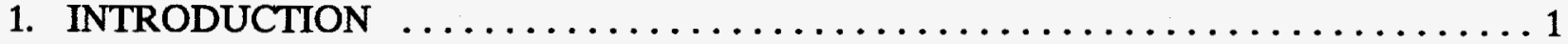

2. SAMPLING DESIGN AND PROCEDURES $\ldots \ldots \ldots \ldots \ldots \ldots \ldots \ldots \ldots \ldots \ldots$

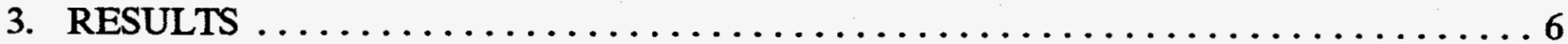

4. DISCUSSION AND CONCLUSIONS $\ldots \ldots \ldots \ldots \ldots \ldots \ldots \ldots \ldots \ldots \ldots \ldots \ldots \ldots$

5. REFERENCES $\ldots \ldots \ldots \ldots \ldots \ldots \ldots \ldots \ldots \ldots \ldots \ldots \ldots \ldots \ldots \ldots \ldots \ldots$

FIGURE

1. Map of the detonation site and sampling locations for snow and ice cores collected following the detonation, and nitrate concentrations $\left(\mathrm{NO}_{3}-\mathrm{N}\right)$ from four sampling depths from each core sample

\section{TABLES}

1. Inventory of materials involved in the detonation of hazardous materials at McMurdo

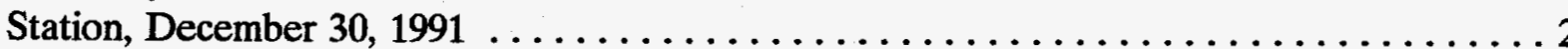

2. Nitrate $\left(\mathrm{NO}_{3}-\mathrm{N}\right)$ concentrations from snow and ice core samples collected following the detonation of chemical materials near McMurdo Station $\ldots \ldots \ldots \ldots \ldots \ldots \ldots \ldots$ 


\section{Nitrate Analysis of Snow and Ice Core Samples Collected in the Vicinity of a Waste Detonation Event, McMurdo Station, Antarctica}

\section{INTRODUCTION}

Explosives were used to dispose of a quantity of hazardous materials at a site near McMurdo Station on December 30,1991. ${ }^{\mathrm{a}}$ The detonation site was located toward Windless Bight and across from Willie Field. The purpose of the detonation was to provide the safest method for disposing these materials. Most of the materials involved were very reactive and could not be safely transported to the continental United States for disposal either by air or by sea. Several of the chemicals detonated during the event were identified as having the potential to form explosive peroxides following prolonged storage. In addition, potentially explosive materials and waste explosives were detonated.

An inventory of the waste chemicals and explosives that were detonated during the event is provided in Table 1.

Due to concerns that the detonation could result in the deposition of contaminants, sampling was conducted in the area surrounding the detonation site on April 21 and 23, 1992. Cores containing both snow and underlying ice were collected and subsequently analyzed for nitrate $\left(\mathrm{NO}_{3}-\mathrm{N}\right)$, an expected product of the event.

\section{SAMPLING DESIGN AND PROCEDURES}

The detonation site is shown in Figure 1 along with the locations of snow and ice core sampling (stars) after the detonation. Also shown are the distances of each sampling location from the center of the detonation area and the results of nitrate analysis (in $\mu \mathrm{g} / \mathrm{L}$ ) for four different sample depths. Sampling was concentrated in the downwind direction, extending to a distance of $160 \mathrm{~m}$. Additional samples were collected upwind and perpendicular to the wind direction and included sites within and outside the detonation crater. Locations up to $37 \mathrm{~m}$ from ground zero in the upwind direction and perpendicular to the wind direction at the time of the detonation were included in the sampling design. Samples were collected at the direction of the National Science Foundation on 21 and 23 April 21 and 23, 1992, by E. Finn, B. Haals, M. Hemphill, and J. Stein, approximately 4 months after the detonation event.

a. The activities described in this report were directed or conducted by the National Science Foundation with the support of Antarctic Support Associates. This report was prepared by EG\&G Idaho to document the sampling and analysis program. EG\&G Idaho was not involved in either the detonation event or the collection of the snow and ice core samples. Analysis of the samples for nitrate was conducted by an EG\&G Idaho subcontractor. 
Table 1. Inventory of materials involved in the detonation of hazardous materials at McMurdo Station, December 30, 1991.

\begin{tabular}{|c|c|c|c|}
\hline Category & Chemical/material & Quantity $^{\mathrm{a}}$ & Container type \\
\hline \multirow{8}{*}{$\begin{array}{l}\text { Potential peroxide- } \\
\text { forming chemicals }\end{array}$} & Acetaldehyde & $2 @ 500 \mathrm{~mL}$ & Glass bottles \\
\hline & 1,4-Dioxane & $\begin{array}{l}9 @ 1 \mathrm{qt} \\
5 @ 1 \mathrm{pt}\end{array}$ & $\begin{array}{l}\text { Glass bottles } \\
\text { Glass bottles }\end{array}$ \\
\hline & Ether, anhydrous & $\begin{array}{l}7 @ 4 L \\
6 @ 4 L \\
4 @ 1 L\end{array}$ & $\begin{array}{l}\text { Glass bottles } \\
\text { Metal cans } \\
\text { Metal cans }\end{array}$ \\
\hline & Ether, diisopropyl & $2 @ 2 L$ & Glass bottles \\
\hline & Methylcyclopentane & $1 @ 1$ qt & Glass bottles \\
\hline & Tert-Butanol & $4 @ 1$ pt & Glass bottles \\
\hline & Tetrahydrofuran & $1 @ 1$ pt & Glass bottles \\
\hline & Tetrahydronaphthalene & $1 @ 4 \mathrm{~L}$ & Glass bottles \\
\hline \multirow{4}{*}{$\begin{array}{l}\text { Potential explosive } \\
\text { chemicals }\end{array}$} & 2,4-Dinitrophenol & $2 @ 100 \mathrm{~g}$ & Glass bottles \\
\hline & 2,4-Dinitrophenylhydrazine & $2 @ 25 \mathrm{~g}$ & Glass bottles \\
\hline & Perchloric acid & $\begin{array}{l}9 @ 8 \mathrm{lb} \\
2 @ 500 \mathrm{~mL}\end{array}$ & $\begin{array}{l}\text { Glass bottles } \\
\text { Glass bottles }\end{array}$ \\
\hline & Picric acid & $\begin{array}{l}2 @ 500 \mathrm{~g} \\
2 @ 100 \mathrm{~g}\end{array}$ & $\begin{array}{l}\text { Glass bottles } \\
\text { Glass bottles }\end{array}$ \\
\hline \multirow[t]{5}{*}{ Waste explosives } & Anzomex cast primers & $3,000 \mathrm{lb}$ & -- \\
\hline & Old DuPont $60 \%$ dynamite & $20 \mathrm{lb}$ & -- \\
\hline & Military-shaped charges & $3 \times 15 \mathrm{lb}$ & -- \\
\hline & UDT satchel charge (C-4) & $40 \mathrm{lb}$ & -- \\
\hline & 400-grain detonation cord & 1 roll & -- \\
\hline
\end{tabular}

a. Quantities listed are as reported to EG\&G Idaho. 


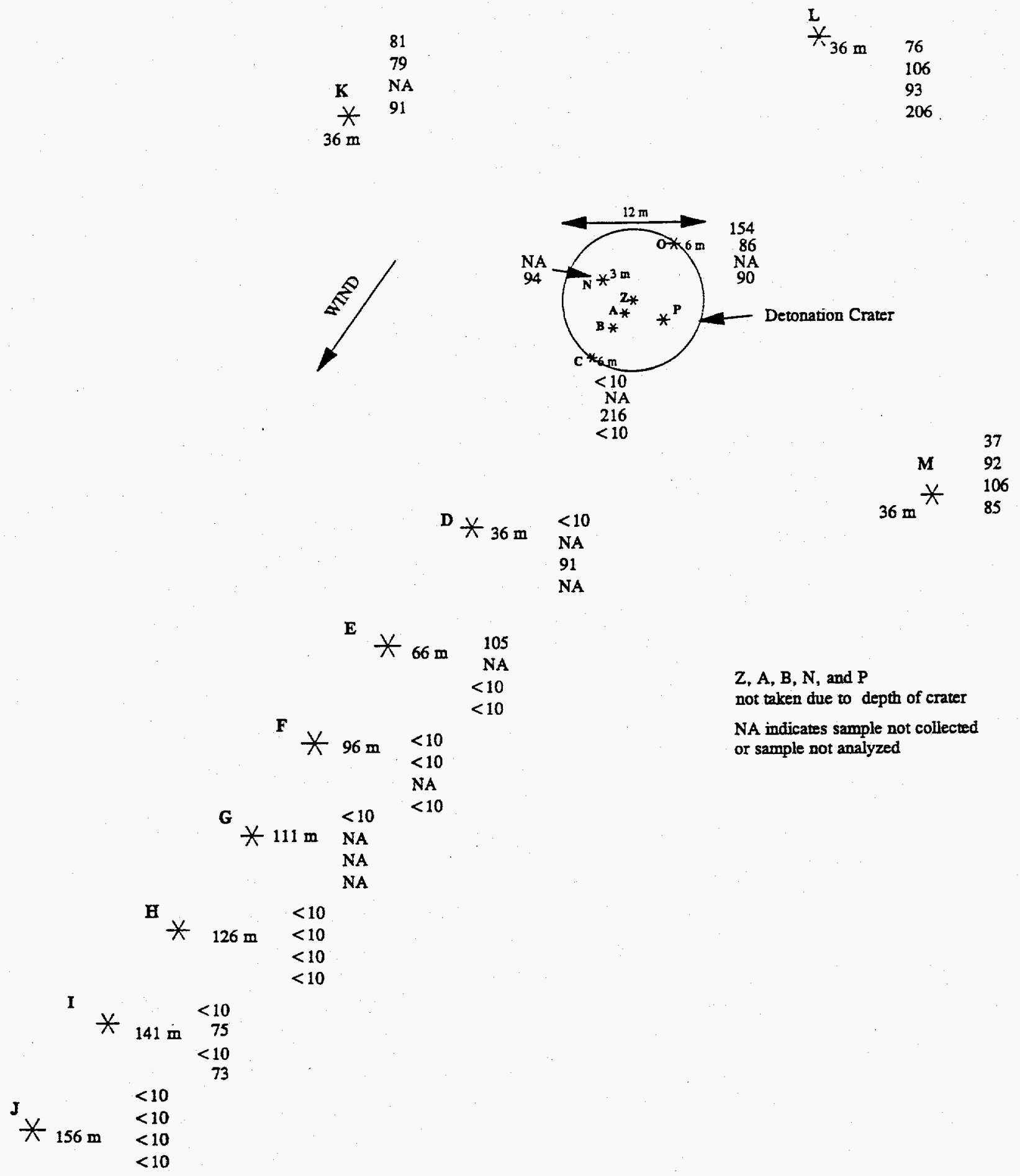

Figure 1. Map of the detonation site and sampling locations for snow and ice cores collected following the detonation, and nitrate concentrations $\left(\mathrm{NO}_{3}-\mathrm{N}\right)$ from four sampling depths from each core sample. 
The samples were collected using a Sipre auger $(7.5 \mathrm{~cm}$ in diameter and $91 \mathrm{~cm}$ long), representing a cross-sectional area of $44 \mathrm{~cm}^{2}$. Depending on the location of the sample with respect to the point of detonation, one to four cores were collected ranging from the surface to a depth of up to $3.6 \mathrm{~m}$. It was reported that surface cores were taken from the margins of the crater, while longer cores were taken from the interior of the detonation crater, presumably to reach near the crater floor, which had filled in with drifting and falling snow. However, the original field sampling map (Figure 1) indicated that the interior crater samples were not collected as originally planned due to the "depth of crater."

The analytical results displayed in Figure 1 are based on the sample identification codes shown in Table 2. It has been assumed that the last character of the sample code refers to the sample depth ("1" indicating a surface sample, descending to " 4 " as the deepest core at a given areal location).

The inside of the Sipre auger barrel was cleaned before each sample was collected using a plunger comprised of paper toweling soaked with ethanol. The plastic sleeve in which the sample was placed for long-term storage was not cleaned. No control samples, blanks, or quality assurance samples were collected, although communication with the samplers indicated that "samples taken at $150 \mathrm{~m}$ west [downwind] of the blast site might be considered" controls.

From the 51 original samples collected, 11 were disposed on February 2, 1993, at the direction of A. J. Brown to make room for the storage of higher priority ice core samples from Vostok Station, and 40 samples were retained for analysis. No record was retained concerning the sample identification codes of the 11 discarded samples. Each sample was stored inside a plastic sleeve with the ends left untied, and was then placed within a Tilson cardboard core tube. A paper card was placed inside the plastic sleeve to indicate the sample number.

From April 1992 until Winfly (August) 1992, the Tilson core tubes containing the samples were stored in triwall boxes on a science cargo line outside, where temperatures ranged from 34.4 to $-40^{\circ} \mathrm{C}$. During Winfly 1992 , the samples were transferred to the TESL freezer in Building 139. Here, the samples were initially stored with frozen food at $-28.8^{\circ} \mathrm{C}$. Later in the season, additional ice cores collected by various science projects were also placed in the freezer. On February 2, 1993, the individual Tilson core tubes were transferred to the Hilltop freezer in Building 145, where biological and glaciological samples plus frozen fish were stored at $-28.8^{\circ} \mathrm{C}$. On February 11, 1993, the sample core tubes were packaged in styrofoam-insulated Tilson boxes (four tubes per box), which were loaded into a freezer van and shipped from McMurdo Station the next day in the hold of the $M / V$ Greenwave. The Greenwave arrived in Port Hueneme, California, on March 17, 1993.

Samples were shipped from Port Hueneme to St. Louis, Missouri, on May 3, 1993, for analysis by Twin City Testing Corporation. Only 39 of the 40 samples were received by Twin City Testing Corporation, with sample $\mathrm{G} / \mathrm{I} / 4$ not arriving with the sample shipment. No explanation was available regarding the status of the missing sample. Upon receipt, the samples were placed in pre-cleaned plastic buckets and allowed to melt at room temperature. The resulting liquid was analyzed for total nitrate nitrogen using ion chromatography (EPA method 300). The samples were divided into two groups, with a matrix spike and duplicate analysis performed on one sample from each group. The analyses were completed within 24 hours of the time the samples were melted. Twin City Testing Corporation reported the data as $\mathrm{NO}_{3}-\mathrm{N}$. 
Table 2. Nitrate $\left(\mathrm{NO}_{3}-\mathrm{N}\right)$ concentrations from snow and ice core samples collected following the detonation of chemical materials near McMurdo Station.

\begin{tabular}{|c|c|c|c|c|}
\hline $\begin{array}{l}\text { Map sample } \\
\text { ID code }\end{array}$ & $\begin{array}{c}\text { Lab sample } \\
\text { number }\end{array}$ & $\begin{array}{l}\text { Distance from ground zero } \\
\text { (m) }\end{array}$ & $\begin{array}{l}\text { Direction } \\
\text { (re: wind) }\end{array}$ & $\begin{array}{l}\text { Concentration } \\
\qquad(\mu \mathrm{g} / \mathrm{L})\end{array}$ \\
\hline $\mathrm{C} / \mathrm{I} / 1$ & 2542 & 6 & Down & $<10$ \\
\hline $\mathrm{C} / \mathrm{I} / 3$ & 2540 & 6 & Down & 216 \\
\hline $\mathrm{C} / \mathrm{I} / 4$ & 2550 & 6 & Down & $<10$ \\
\hline $\mathrm{D} / \mathrm{T} / 1$ & 2543 & 36 & Down & $<10$ \\
\hline $\mathrm{D} / \mathrm{I} / \mathbf{3}$ & 2541 & 36 & Down & 91 \\
\hline $\mathrm{E} / \mathrm{I} / \mathbf{1}$ & 2554 & 66 & Down & 105 \\
\hline $\mathrm{E} / \mathrm{I} / \mathbf{3}$ & 2539 & 66 & Down & $<10$ \\
\hline $\mathrm{E} / \mathrm{I} / 4$ & 2553 & 66 & Down & $<10$ \\
\hline $\mathbf{F} / \mathbf{I} / 1$ & 2574 & 96 & Down & $<10$ \\
\hline $\mathrm{F} / \mathrm{I} / 2$ & 2559 & 96 & Down & $<10$ \\
\hline $\mathrm{F} / \mathrm{I} / 4$ & 2563 & 96 & Down & $<10$ \\
\hline $\mathrm{G} / \mathrm{I} / 1$ & 2544 & 111 & Down & $<10$ \\
\hline $\mathrm{H} / \mathrm{I} / 1$ & 2573 & 126 & Down & $<10$ \\
\hline $\mathrm{H} / \mathrm{I} / 2$ & 2566 & 126 & Down & $<10$ \\
\hline $\mathrm{H} / \mathrm{I} / 3$ & 2561 & 126 & Down & $<10$ \\
\hline $\mathrm{H} / \mathrm{I} / 4$ & 2565 & 126 & Down & $<10$ \\
\hline $\mathbf{I} / \mathbf{I} / 1$ & 2538 & 141 & Down & $<10$ \\
\hline $\mathrm{I} / \mathrm{I} / 2$ & 2570 & 141 & Down & 75 \\
\hline $\mathrm{I} / \mathrm{I} / \mathbf{3}$ & 2568 & 141 & Down & $<10$ \\
\hline $\mathrm{I} / \mathrm{I} / 4$ & 2537 & 141 & Down & 73 \\
\hline $\mathrm{J} / \mathrm{I} / \mathbf{1}$ & 2546 & 156 & Down & $<10$ \\
\hline $\mathrm{J} / \mathrm{I} / 2$ & 2558 & 156 & Down & $<10$ \\
\hline $\mathrm{J} / \mathrm{I} / \mathbf{3}$ & 2567 & 156 & Down & $<10$ \\
\hline $\mathrm{J} / \mathrm{I} / 4$ & 2560 & 156 & Down & $<10$ \\
\hline $\mathrm{K} / \mathrm{I} / 1$ & 2569 & 36 & $90^{\circ}$ & 81 \\
\hline $\mathrm{K} / \mathrm{I} / 2$ & 2552 & 36 & $90^{\circ}$ & 79 \\
\hline $\mathrm{K} / \mathrm{I} / 4$ & 2571 & 36 & $90^{\circ}$ & 91 \\
\hline $\mathrm{L} / \mathrm{I} / \mathbf{1}$ & 2545 & 36 & Up & 76 \\
\hline $\mathrm{L} / \mathrm{I} / 2$ & 2549 & 36 & Up & 106 \\
\hline $\mathrm{L} / \mathrm{I} / 3$ & 2555 & 36 & Up & 93 \\
\hline $\mathrm{L} / \mathrm{I} / 4$ & 2551 & 36 & Up & 206 \\
\hline $\mathrm{M} / \mathrm{I} / 1$ & 2556 & 36 & $270^{\circ}$ & 37 \\
\hline $\mathrm{M} / \mathrm{I} / 2$ & 2575 & 36 & $270^{\circ}$ & 92 \\
\hline $\mathrm{M} / \mathbf{I} / \mathbf{3}$ & 2572 & 36 & $270^{\circ}$ & 106 \\
\hline $\mathrm{M} / \mathrm{I} / 4$ & 2547 & 36 & $270^{\circ}$ & 85 \\
\hline $\mathrm{N} / \mathrm{I} / 2$ & 2562 & 3 & $90^{\circ}$ & 94 \\
\hline $\mathrm{O} / \mathrm{I} / 1$ & 2557 & 6 & Up & 154 \\
\hline $\mathrm{O} / \mathrm{I} / 2$ & 2548 & 6 & Up & 86 \\
\hline $\mathrm{O} / \mathrm{I} / 4$ & 2564 & 6 & Up & 90 \\
\hline
\end{tabular}




\section{RESULTS}

The results of the ice core analysis for $\mathrm{NO}_{3}-\mathrm{N}$ are shown in Table 2 and Figure 1. Nineteen of the 39 samples contained $\mathrm{NO}_{3}-\mathrm{N}$ concentrations that were below the detection limit of $10 \mu \mathrm{g} / \mathrm{L}$. The other 20 samples contained $\mathrm{NO}_{3}-\mathrm{N}$ at concentrations ranging from 37 to a maximum of $216 \mu \mathrm{g} / \mathrm{L}$. The arithmetic mean for the 39 results is $63.5 \mu \mathrm{g} / \mathrm{L}$ (using a value of $5 \mu \mathrm{g} / \mathrm{L}$ for all samples below $10 \mu \mathrm{g} / \mathrm{L})$.

\section{DISCUSSION AND CONCLUSIONS}

Overall, the data indicate that detectable levels of $\mathrm{NO}_{3}$ exist in the vicinity of the detonation site. Concentrations are variable, nonuniform, and do not exhibit any definitive trend or pattern because nitrate levels in the upwind direction appear to be at least as high as those collected in the three other directions.

Nitrate concentrations in snow and ice samples in Antarctica have been reported from a number of earlier studies. At the South Pole, average surface snow nitrate concentrations of $89.2 \mathrm{ng} / \mathrm{g}\left(20.1 \mu \mathrm{g} / \mathrm{L} \mathrm{NO}_{3}-\mathrm{N}\right)$ were reported by Legrand and Delmas (1990). Higher concentrations averaging $183 \mathrm{ng} / \mathrm{g}$ nitrate $\left(41.3 \mu \mathrm{g} / \mathrm{L} \mathrm{NO}_{3}-\mathrm{N}\right)$ have also been reported for the South Pole (Zeller and Parker, 1981). Scientists studying the nitrate signal of solar flares in polar snow and ice obtained core samples during the 1990-1991 field season from the Windless Bight area. Results of the cores that were collected from the surface to a depth of $29 \mathrm{~m}$ ranged from $<5 \mu \mathrm{g} / \mathrm{L}$ to as high as $120 \mu / \mathrm{L}$; nitrate concentrations in the 1990-1991 time frame ranged from $10 \mu \mathrm{g} / \mathrm{L}$ to $55 \mu \mathrm{g} / \mathrm{L}$. The mean concentration for the entire $29-\mathrm{m}$ core length was approximately $20 \mu \mathrm{g} / \mathrm{L}$ (Dreschoff and Zeller, 1992). Therefore, the mean value of $63.5 \mu \mathrm{g} / \mathrm{L}$ from this study is slightly higher than the maximum value measured during the same time frame by Dreschoff and Zeller (1992).

Several problems prevent drawing other conclusions regarding the impact of the detonation event on local nitrate concentrations in snow. The 4-month delay between the detonation event and the sampling makes interpretation of the results difficult because nitrates may have migrated with blowing snow or by other means. Furthermore, the concentrations within the crater may be reduced by the influx of clean snow drifting into the crater prior to sampling. Holding times and storage techniques could also influence the precision of the analysis.

The lack of quality assurance measures also poses problems in the evaluation of these sample results. No definitive control samples were collected from areas known to be unaffected by the detonation; however, since almost half the samples collected exceeded the detection limit of $10 \mu \mathrm{g} / \mathrm{L}$, the detection limit value can be considered a "control" value. Field blanks to assess the potential for cross contamination of sampling equipment were not collected; however, the presence of results below the detection limit provides de facto assurance that there was no significant problem with cross contamination.

The only solid conclusion that can be drawn from the data concerns the mean nitrate concentrations found in the samples collected, and several caveats must be placed on these values to account for the time delays between the detonation, sampling, and analysis. If it may be 
assumed that the analytical results are representative of the actual environmental nitrate levels of the snow and ice surrounding the detonation site, then the reported levels are in the same order of magnitude as background levels, and would not be expected to negatively impact the local environment. It would be prudent that programs designed to sample snow and ice for measuring "natural" background levels (e.g., studies of nitrate signals of past solar flares) avoid the detonation area in the future, recognizing the possibility of the presence of detonation-based nitrates.

\section{REFERENCES}

Dreschoff, G. A. and E. J. Zeller, 1992, A Nitrate Signal of Solar Flares in Polar Snow and Ice, Annual Technical Report AD-A260 559, prepared for Air Force Office of Scientific Research, Bolling Air Force Base, Washington, D.C.

Legrand, M. R. and R. J. Delmas, 1990, "The Ionic Balance of Antarctic Snow: A 10-year Detailed Record," Atmospheric Environment, 18, pp. 1867-1874.

Zeller, E. J. and B. C. Parker, 1981, "Nitrate Ion in Antarctic Firn as a Marker for Solar Activity," Geophysical Research Letters, 8, pp. 895-898. 